\title{
NEW SPECIES OF WEDELIA (ASTERACEAE, HELIANTHEAE) FROM MEXICO AND CRITICAL ASSESSMENT OF PREVIOUSLY DESCRIBED TAXA
}

\author{
B.L. Turner
}

Department of Botany, University of Texas, Austin, Texas 78713 U.S.A.

\section{ABSTRACT}

Two new species, Wedelia pimana B. Turner and W. talpana B. Turner, occurring in Chihuahua and Jalisco, respectively, are described as new. In addition, justification is given for the acceptance of $W$. gentryi B. Turner, and W. cronquistii B. Turner, both of which were treated as synonyms of $W$. greenmanii B. Turner, in Strother's (1991) treatment of the genus for North America; evidence is also presented for the submergence of $W$. tegetis Strother in the earlier $W$. mexicana (Schultz-Bip.) McVaugh. When appropriate, distributional maps of these several taxa are provided.

KEY WORDS: Wedelia, Asteraceae, México

Appearance of the carefully constructed revisional study of the North American species of Wedelia and related groups by Strother (1991) has occasioned the present study, largely because the nomenclature proposed by him has impinged upon my treatment of the Mexican species (Turner \& Nesom, in prep.). Strother recognized seventeen species as occurring in México (excluding $W$. trilobata L., which he included in the newly proposed genus Complaya Strother). In addition, he recognized seven infraspecific taxa in his concept of the widespread highly variable $W$. acapulcensis Kunth complex, all of these occurring in México. Strother, in his basically conservative treatment, also called to the fore one or more set of specimens which he thought might ultimately prove deserving of specific status.

In my own appraisal of Wedelia in North America (largely based upon the study of material at ARIZ,ASU,CAS,F,GH,LL,MEXU,MICH,TEX, and WIS (including most of the types for the names concerned) I would recognize 23 specific taxa as occurring in México (excluding the probably introduced $W$. trilobata), two of these described in the present contribution. Additionally, 
while I agree with many of Strother's taxonomic conclusions, I cannot accept his broadly inclusive treatment of Wedelia acapulcensis, and yet other taxa. Because of this, I place on record here my reasons for rejecting some of the taxonomy proposed by him, and the nomenclature that might accompany such rejection.

Wedelia pimana B. Turner, sp. nov. TYPE: MEXICO. Chihuahua: "small grassy area above a small waterfall not more than $100 \mathrm{~m}$ from the center of town [Nabogame] ... a somewhat anomalous area in the vicinity, sunlit with a stream flowing right through the middle towards the waterfall. The parent rock material in that area was a purplish-red shale which generally made for richer soil than the siliceous rhyolite on the east side of the valley.", $1800 \mathrm{~m}, 3$ Aug 1987, J.E. Laferrière 646 (HOLOTYPE: TEX; Isotype: ARIZ). The quoted information is taken from a letter to the present author from the collector, dated 5 Dec 1991.

Wedeliae scabrae (Cav.) B. Turner similis sed floribus radii neuteris et foliis valde laceratis differt.

Suffruticose erect herbs to $70 \mathrm{~cm}$ high. Stems reddish, pubescent throughout with coarse spreading hairs to $1 \mathrm{~mm}$ long, these interspersed among a finer hispidulum of much shorter hairs, some of them uncinate or apically recurved. Leaves opposite, scarcely reduced upwards, mostly $5-7 \mathrm{~cm}$ long, $1.5-2.0 \mathrm{~cm}$ wide; petioles $2-4 \mathrm{~mm}$ long, pubescent like the stems; blades ovate to ovate lanceolate in outline, principal nerves 3 , pubescent beneath like the stems, but the surface also subglandular, or glandular, the margins markedly lacerate or sublobate. Heads arranged 3-5 in terminal cymes, the ultimate peduncles mostly $2-6 \mathrm{~cm}$ long. Involucres campanulate, ca. $1 \mathrm{~cm}$ high, $0.8-1.0 \mathrm{~cm}$ wide, the bracts linear-lanceolate, subequal, spreading hirsute with stiff white hairs. Receptacle convex, the pales linear-lanceolate, $8-10 \mathrm{~mm}$ long, readily detached, the single dorsal nerve purple, the apices acute. Ray florets ca. 8 , neuter; corollas yellow, the tubes glabrous, ca. $3 \mathrm{~mm}$ long, the ligules $5-8 \mathrm{~mm}$ long, ca. 2 $\mathrm{mm}$ wide. Disk florets ca. 35 , the corollas yellow, $6-7 \mathrm{~mm}$ long, glabrous, the tubes ca. $2.5 \mathrm{~mm}$ long, the lobes narrowly acute, ca. $1.5 \mathrm{~mm}$ long. Achenes ca. $5 \mathrm{~mm}$ long, 2.2-2.5 mm wide, wingless, moderately appressed pubescent, the pappus of 2 principal awns 1-3 mm long, between these a shorter, lacerate, crown of scales, the base with a distinct elaiosome.

Strother (1991) called attention to the present taxon, noting, "I thought that this odd collection [646] might represent a hybrid between the two [Wedelia chihuahuana and $W$. greenmanii]. I found pollen stainability ... to be $98 \%$ for a single floret from Laferrière. Perhaps the specimen will prove referable to a distinct taxon." 
Additional study, and correspondence with Laferrière (cited, in part, above and below) has convinced the present worker that the plant concerned represents a good species, presumably a localized endemic with distant relationships to the widespread Wedelia scabra (sensu Turner 1988), to judge from the vestiture, but perhaps equally close to $W$. chihuahuana. I assigned the collection concerned to the latter taxon initially, but $W$. pimana differs in habit, vestiture and details of the disk florets (having glabrous lanceolate lobes vs. hispidulous and deltoid).

I had intended to name this taxon for its only known collector, Dr. Joseph E. Laferrière, who has made a remarkable series of collections of the region concerned in connection with an ethnobotanical study of the Mountain Pima of Chihuahua. However, the collector deigned have his name eponymized, suggesting instead the name pimana, which is adopted here.

Wedelia talpana B. Turner, sp. nov. Fig. 1. TYPE: MEXICO. Jalisco: Mpio. Talpa, km 9 of the road to Minas del Cuale, 1050 m, 7 Mar 1992, J.L. Panero, Lidia Cabrera, \& A. Campos 2858 (HOLOTYPE: MEXU; Isotype: TEX).

Wedeliae rosei (Greenm.) McVaugh similis sed foliis minoribus (plerumque $2-3 \mathrm{~cm}$ longis vs. $3-8 \mathrm{~cm}$ ) marginibus involutis ac paginis infernis brevi-hispidulis et capitulis plerumque 2-3 subsessilibus (in pedunculis $2-10 \mathrm{~mm}$ longis) in aggregatis differt.

Brittle stemmed low shrubs or shrublets 20-30 $\mathrm{cm}$ high. Stems densely hispid-pilose. Leaves opposite, mostly $20-30 \mathrm{~mm}$ long, $3-8 \mathrm{~mm}$ wide; petioles 1-2 mm long; blades narrowly lanceolate to ovate elliptic, harshly pubescent above and below with erect or ascending hairs, the surface itself somewhat glandular-furfuraceous, the margins mostly enrolled and seemingly entire. Heads campanulate, mostly arranged in aggregations of 2-3 nearly sessile heads, when single, the peduncles $2-10 \mathrm{~mm}$ long. Involucres mostly $7-11 \mathrm{~mm}$ high, the bracts subgraduate to subequal in 2-3 series, the outer series herbaceous and pilose, the inner series scarious, ciliate, and with purple striations. Receptacle convex, the bracts lanceolate with purple midribs. Ray florets 5-8, neuter, sterile; tubes glabrous, ca. $2 \mathrm{~mm}$ long; ligules yellow, 5-7 mm long. Disk florets ca. 30 ; corollas ca. $5 \mathrm{~mm}$ long, yellow, glabrous or nearly so, the tubes ca. $1.5 \mathrm{~mm}$ long, the limbs $3.0-3.5 \mathrm{~mm}$ long, the lobes ca. $0.7 \mathrm{~mm}$ long, sparsely hispidulous. Anther sacs black, the appendages yellow. Achenes obovoid, very plump, 3.5-4.0 $\mathrm{mm}$ long, ca. $2 \mathrm{~mm}$ wide, the surface black and finely striate, rather evenly, but moderately pilose throughout, the base with a well developed elaiasome; pappus a crown of short fimbriate scales arising from a boss or neck ca. $0.4 \mathrm{~mm}$ high. 


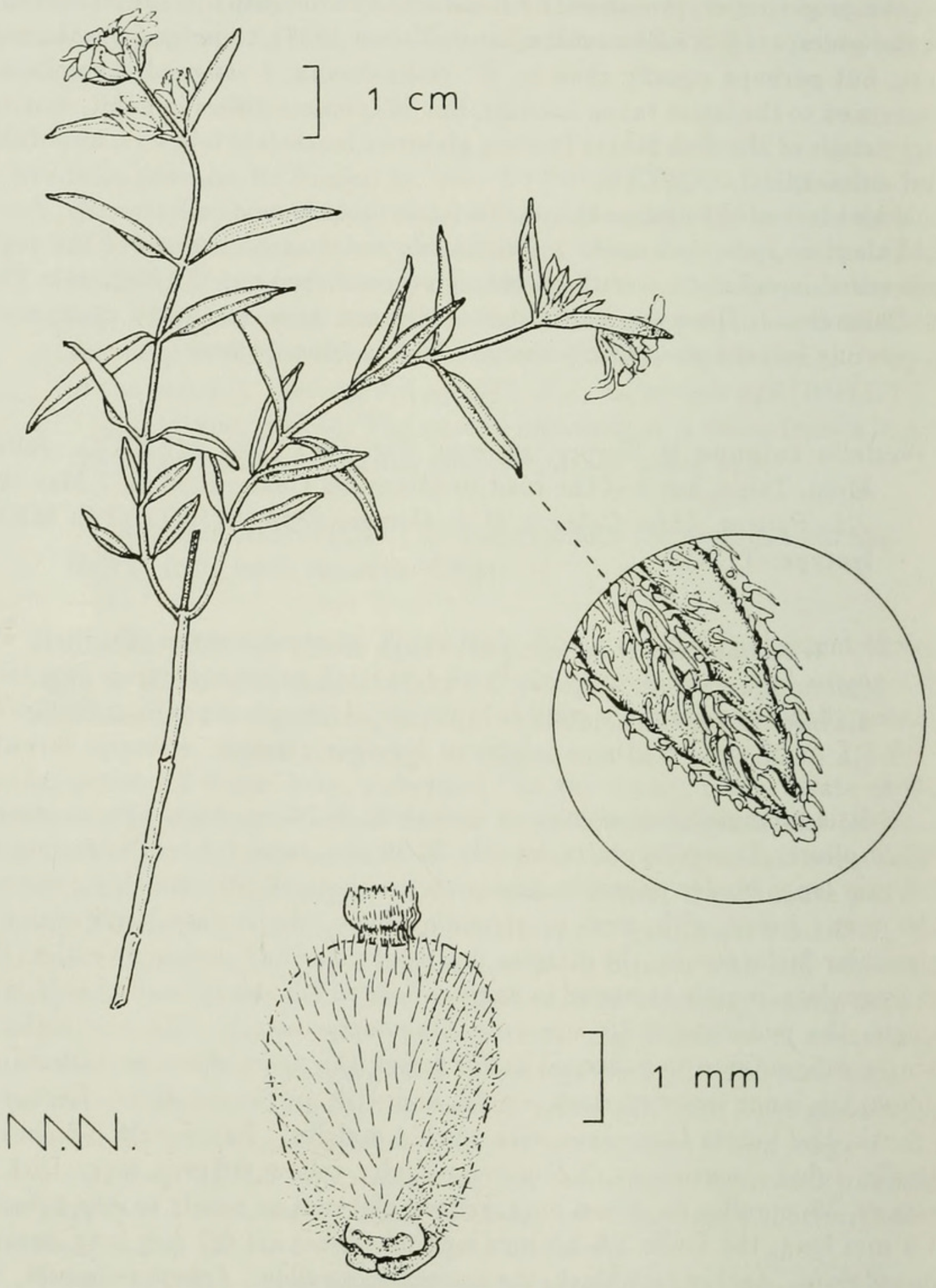

Fig. 1. Wedelia talpana (from Diaz L. 20971, TEX). 
ADDITIONAL SPECIMENS EXAMINED: MEXICO. Jalisco: Mpio. de Cabo Corrientes, 3-10 km generally east on the road to Mina del Cuale, from the junction $5 \mathrm{~km} \mathrm{NW}$ of El Tuito, 850-1150 m, 16-19 Feb 1975, McVaugh $26367(\mathrm{MICH}) ;$ Mpio. Talpa, km 18 along the road from El Tuito to La Mina de Zimapán, 1850 m, 14 Oct 1989, Diaz L. \& Lomeli S. 20971 (TEX); between Cumbre del Tejamanil and Cuale, $1790 \mathrm{~m}, 6 \mathrm{Mar} 1971, R$. Gonzales T. 125 (ENCB,MICH).

Strother (1991) called attention to two of the above cited specimens, noting that "On further study, supplemented by additional collections, these may prove to represent a distinct species." With the collection of additional specimens from the area concerned (including the type), which possess all of the characters called to the fore in the above description, I have no hesitation in making formal its recognition. According to J. Panero (pers. comm.), who collected the type, the species was relatively common in the area concerned.

\section{Wedelia aggregata (Greenm.) B. Turner}

In my transfer of this taxon from the genus Aspilia (Turner 1988), not having examined its type, I accepted McVaugh's (1984) viewpoint that Wedelia aggregata was but an aberrant form of the well known, widely distributed, $W$. rosei. So treated, the correct name for the taxon would be that of the earlier name, $W$. aggregata. Having now examined type material (GH!) of the latter, I concur with Strother's interpretation: $W$. aggregata appears to be a good morphological species known only from type material.

\section{Wedelia gentryi B. Turner}

Strother placed this name in synonymy within his concept of Wedelia greenmanii B. Turner. I have equivocated in my acceptance of these two taxa (pers. comm. to Strother), largely because at the time of my study Strother had most of the types, and material relating to these, under purview. I have now examined the entire complex and conclude that two good taxa are involved: $W$. gentryi and $W$. greenmanii. The latter is readily distinguished from the former by its very minute, closely appressed, strigose hairs, these occurring in a rather uniform fashion on the foliage, stems and involucral bracts. Wedelia gentryi possesses uniformly larger and longer, erect or ascending, hairs on all of its vegetative parts and usually has broader midstem leaves with blades rather clearly trinervate below (vs. mostly uninervate or pinnately nervate, not clearly trinervate below).

So far as known plants referable to Wedelia greenmanii and $W$. gentryi have not been found to occur together, nor have I seen clear intermediates between these. That they are sympatric or nearly so, cannot be doubted, as shown in 


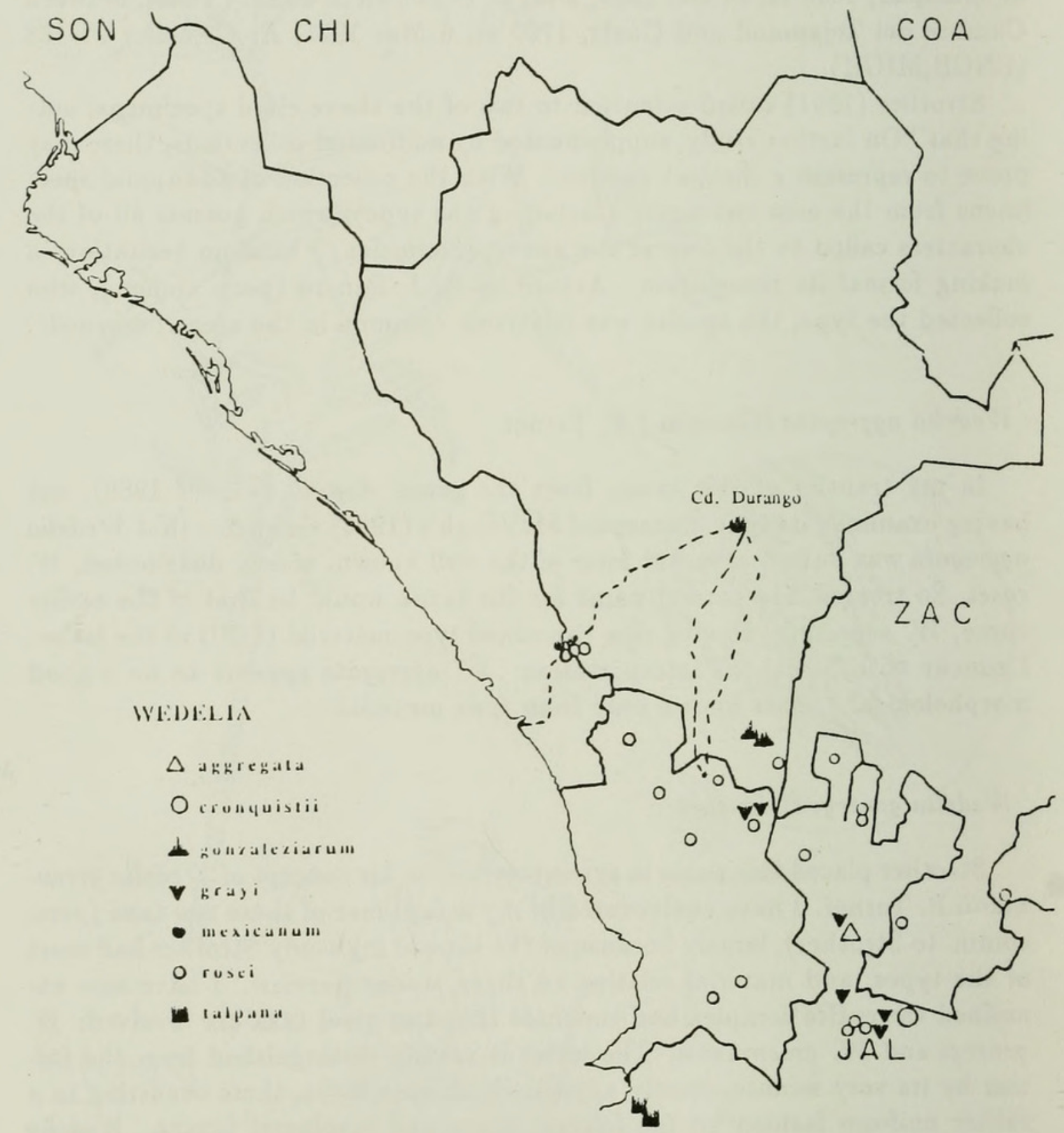

Fig. 2. Distribution of Wedelia spp with respect to Secmann's 18+9-50 trip to the "Sierra Madre". 
Fig. 3. Indeed; since both $W$. greenmanii and $W$. gentryi occur in relatively close proximity in the area of Nabogame, Chihuahua (ca. $28^{\circ} 30^{\prime} \mathrm{N}, 108^{\circ} 30^{\prime}$ W), both collected by Dr. J.E. Laferrière while engaged in an ethnobotanical study of the region concerned ( $W$. gentryi 1101 [ARIZ,TEX]; W. greenmanii 1186,1950 [ARIZ,TEX]), I requested that the collector assess their niche relationships, if any, within this region (including that of $W$. pimana, quoted in the above account). He replied as follows:

Collection \#646 [W. pimana] was from a small grassy area above a small waterfall not more than $100 \mathrm{~m}$ from the center of town. It was a somewhat anomalous area in the vicinity, sunlit with a stream flowing right thru the middle toward the waterfall. The parent rock material in that area was a purplish-red shale which generally made for richer soil than the siliceous rhyolite on the east side of the valley. \#1101 [W. gentryi] was from a very different area about a mile east, in a riparian pine/oak/Cupressus arizonica forest in the rhyolite area. \#1186 and \#1187 [W. greenmanii] were from a dry granitic site about half a mile west of town. That area was composed of many small but steep hills, large boulders, and small cliffs; "the maze" I used to call it because it was often difficult to weave my way thru the broken terrain. I made two separate collections of the Wedelia there because the first had reddish stems, the second grayish-brown stems, a slight difference, but in the field it can be hard to tell what is significant ...]

Hence to answer your question about habitats, the three areas were quite different habitats, both in soil and in dominant vegetation. Another difference is that the 646 site was grazed only in the winter, the others all year round. Given the limited number of collections, however, it can be difficult to say whether these observations would hold up if someone went down to make a more detailed survey.

Since the original description of Wedelia gentryi (Turner 1988), known then only by the type (collected in Sierra Surotato, Sinaloa), I have examined the above mentioned collection of Laferrière, that of Breedlove \& Thorne 18403 (MICH), and Pennington 92 (TEX), all of these examined by Strother and cited as $W$. greenmanii. In short, my examination of most of the material examined by Strother that relates to this complex has reaffirmed my original conviction that two taxa are involved, which I opt to treat as species, there being little suggestion, if any, that the characters which mark them intergrade.

Finally, it should be noted that Strother also placed Wedelia cronquistii B. Turner in synonymy under his concept of $W$. greenmanii. This is discussed in more detail, as follows. 


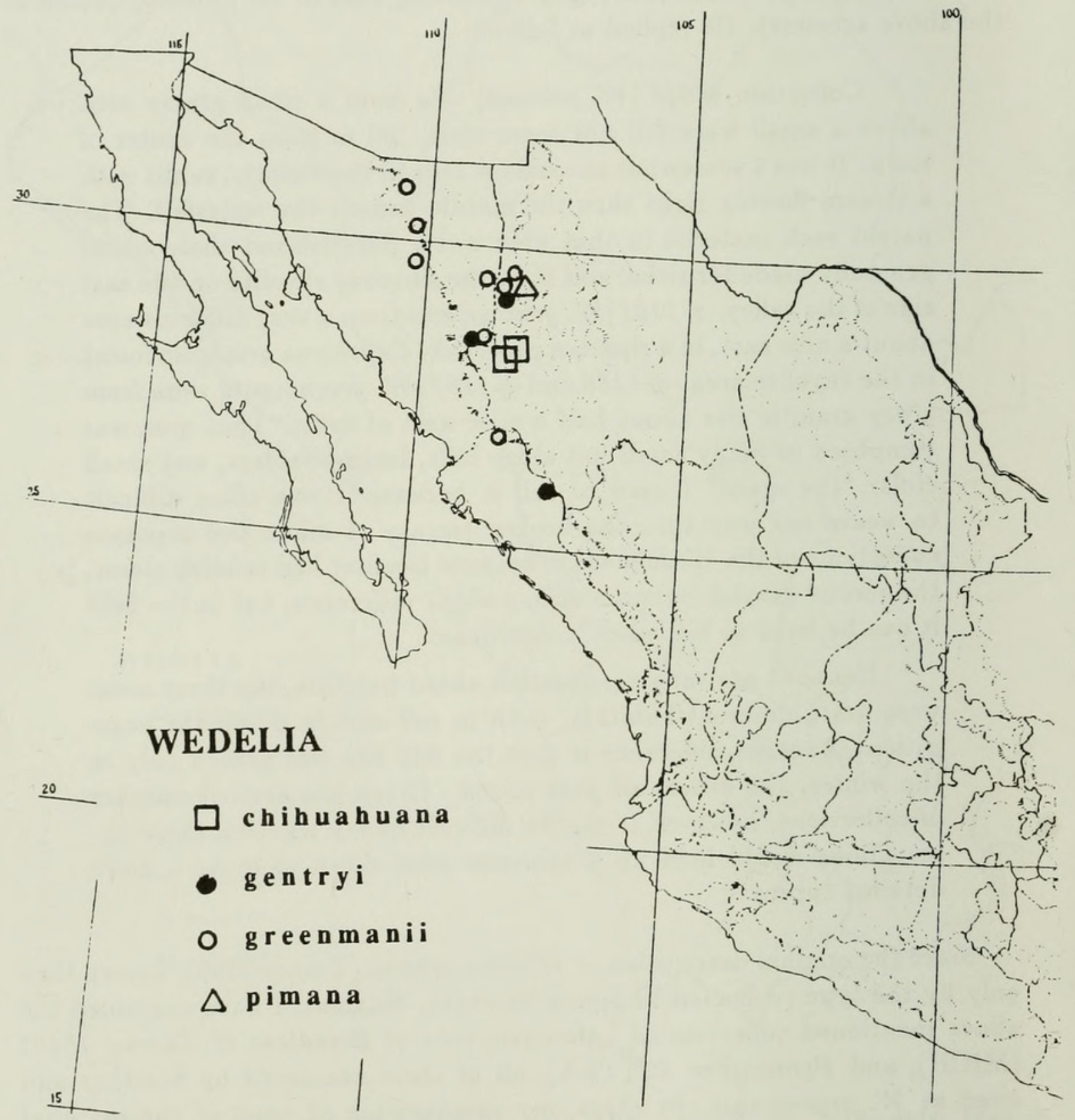

Fig. 3. Distribution of Wedelia spp. 


\section{Wedelia cronquistii B. Turner}

This taxon is known only by the type, collected just east of Guadalajara, Jalisco (Fig. 4). Strother contends (p. 77) that the type differs "from other specimens of Wedelia greenmanii primarily in the greater density, but not in the quality, of the foliar indument of the plants from the disjunct population in Jalisco." Actually, the leaves, and vestiture on undersurfaces of these, differ markedly from those of both $W$. greenmanii (which, as noted above, has a very minute appressed pubescence) and $W$. gentryi (which has scattered, longer, nonappressed, hispid hairs, these occurring on relatively broad, trinervate, midstem leaves), having narrow, highly reticulate venose, undersurfaces and a vestiture of closely strigose or closely packed short or suberect conical hairs. In fact, one might more certainly position $W$. cronquistii within an expanded $W$. rosei than within $W$. greenmanii, for its habital aspects are more like the former and, of course, such a position would make better biogeographical sense; indeed, I suspect that more intensive study will show that the population referable to $W$. cronquistii is closer to both $W$. rosei and $W$. gonzaleziarum B. Turner (from southernmost Durango) sensu Strother, than it is to the morphologically and geographically more remote $W$. greenmanii. In short, I intend to retain $W$. cronquistii, believing this to be a localized endemic in the area concerned, much as appears to be the case for $W$. aggregata, W. gonzaleziarum, W. pimana, and W. talpana, all localized and seemingly distinct species.

\section{Wedelia mexicana (Schultz-Bip.) McVaugh}

Strother recognized this taxon, but believed it to be known only by the type, collected somewhere between Mazatlán, Sinaloa and Cd. Durango, Durango, or possibly between the latter and northern Nayarit, areas traversed by Seemann, who collected in this region from 23 Nov 1849 to 22 Feb 1850 (cf. stippled lines, Fig. 2). Strother distinguished Wedelia mexicana from his newly described $W$. tegetis Strother by internode length (mostly $2-5 \mathrm{~cm}$ long in $W$. mexicana vs. $0.5-1.5 \mathrm{~cm}$ ) and shape of leaf blades (mostly deltate to ovate, rounded to subtruncate at base in $W$. mexicana vs. elliptic to lanceolate, cuneate at the base). I do not find these compelling differences; indeed, a photograph of the type collection housed at $\mathrm{K}(\mathrm{GH}$ !) shows that a range of leaf shapes varying from deltoid to elliptic lanceolate occurs among the several shoots attached to that sheet; in addition, there is much variation in internode length. Besides, nearly all of the species of Wedelia are notoriously variable as regards leaf shape and internode length, as any cursory examination of specimens of this or that species will show. In short, I suspect that Strother's $W$. tegetis is the same as $W$. mexicana. Indeed, it is likely that Seemann collected the type of $W$. mexicana in the same general area from which the type of 


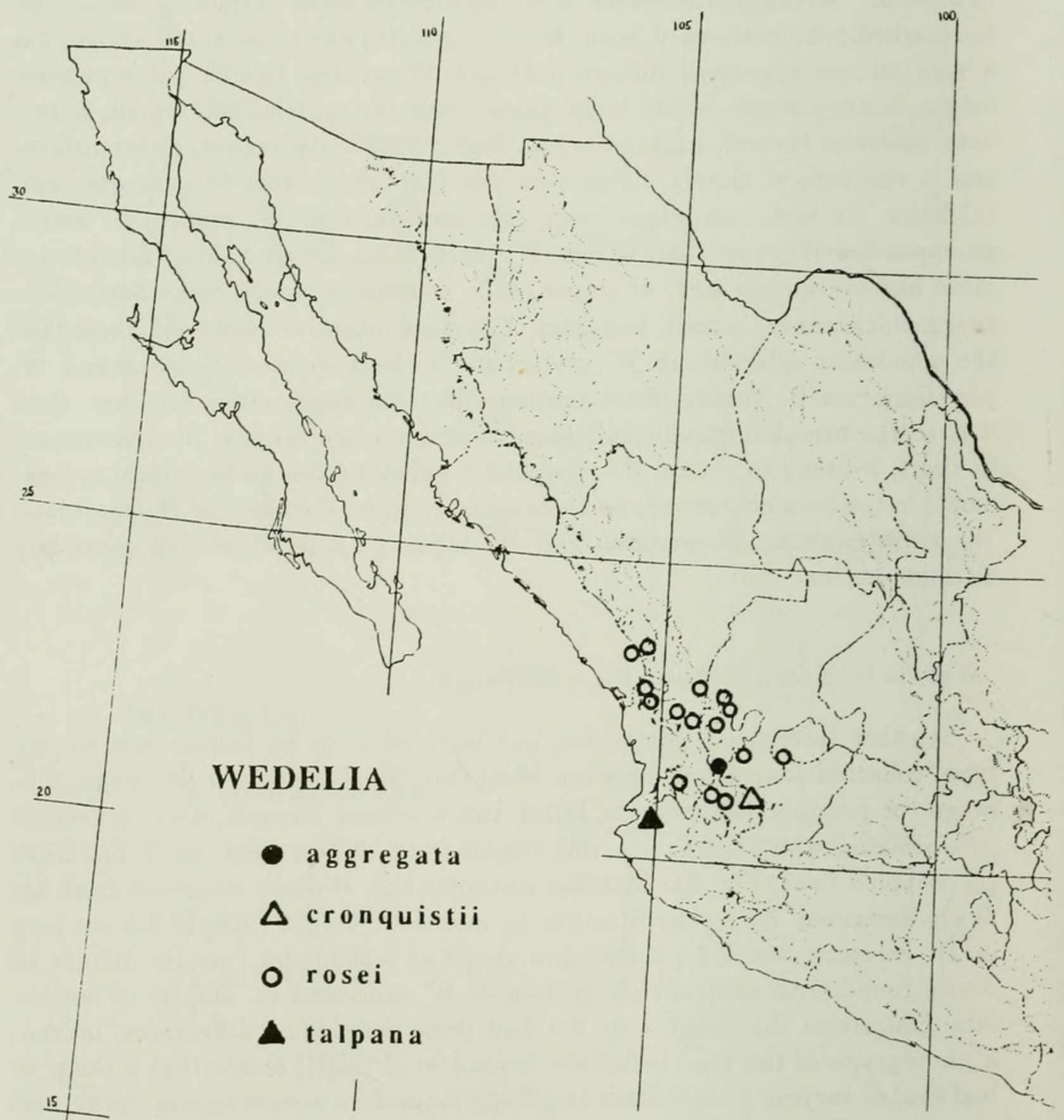

Fig. 4. Distribution of Wedelia spp. 
W. tegetis was obtained, for his journey to $\mathrm{Cd}$. Durango took him directly through the route (along present day Mexican Highway 40) along which the type locality of $W$. tegetis occurs. Numerous recent workers have collected along this route and forms referable to both $W$. tegetis and $W$. mexicana are invariably collected along the Sinaloa-Durango border (Concordia, Sinaloa to El Espinazo del Diablo, Durango). Following his arrival in Cd. Durango, Seemann left the city on 2 Jan 1850 , taking a southerly route through Mezquital, Durango, then hence to Santa Maria (northernmost Nayarit) from whence he returned to Cd. Durango via a more westerly route (through La Guajolota, Durango). He returned hastily to Mazatlán over the same route (along present day Highway 40) he had traversed earlier, arriving in that port city on 22 Feb 1850 .

The important part of the above, which I have taken from Seemann's own account of his travels as given in the Voyage of the Herald, is that the only place $W$. tegetis (or W. mexicana) is known to occur in the region traversed by Seemann, is along the Sinaloa-Durango border (Fig. 2). The route south of Cd. Durango to Santa Maria, Nayarit, has now been fairly well collected and only $W$. rosei, $W$. gonzaleziarum, or $W$. grayi McVaugh has been obtained near or along this route. Strother, however, cites two white rayed plants (MICH!) of W. tegetis from the area near Jesus Maria, Nayarit (Fig. 3) but I would include both of these, somewhat aberrant collections, in my concept of $W$. grayi, which is distinguished from $W$. mexicana by its white rays and longer, more oblanceolate, leaf blades.

The above discourse relating to Wedelia tegetis may be more academic than need be, for Strother (p. 83) wisely notes that "As more specimens become available ... the type of one or more of the names $W$. grayi, $W$. hintoniorum B. Turner, and $W$. tegetis may prove to be conspecific with that of $W$. mexicana." My only quibble here is, that based on the material available at the present time, it is almost certain that $W$. tegetis is the same as $W$. mexicana.

\section{ACKNOWLEDGMENTS}

I am grateful to Guy Nesom for the Latin diagnoses and to him and T.P. Ramamoorthy for reviewing the manuscript. Special thanks are due Dr. J.E. Laferrière for providing me with information relating to the occurrence of Wedelia greenmanii, $W$. gentryi, and $W$. pimana in the area of Nabogame, Chihuahua. Dr. José Panero kindly provided material from his collections (after my preliminary study) for the typification of $W$. talpana. 


\section{LITERATURE CITED}

McVaugh, R. 1984. Compositae. In Flora Novo-Galiciana, ed. W.R. Anderson, 12:1-1157. University of Michigan Press, Ann Arbor, Michigan.

Strother, J.L. 1991. Taxonomy of Complaya, Elaphandra, Iogeton, Jefea, Wamalchitamia, Wedelia, Zexmenia, and Zyzyxia (Compositae-HeliantheaeEcliptinae). Syst. Bot. Monogr. 33:1-111.

Turner, B.L. 1988. New species names and combinations in Wedelia (Asteraceae - Heliantheae). Phytologia 65:348-358. 


\section{$2 \mathrm{BHL}$ Biodiversity Heritage Library}

Turner, B. L. 1992. "New species of Wedelia (Asteraceae, Heliantheae) from Mexico and critical assessment of previously described taxa." Phytologia 72, 115-126. https://doi.org/10.5962/bhl.part.14866.

View This Item Online: https://www.biodiversitylibrary.org/item/47381

DOI: https://doi.org/10.5962/bhl.part.14866

Permalink: https://www.biodiversitylibrary.org/partpdf/14866

\section{Holding Institution}

New York Botanical Garden, LuEsther T. Mertz Library

\section{Sponsored by}

The LuEsther T Mertz Library, the New York Botanical Garden

\section{Copyright \& Reuse}

Copyright Status: In copyright. Digitized with the permission of the rights holder.

Rights Holder: Phytologia

License: http://creativecommons.org/licenses/by-nc-sa/3.0/

Rights: https://biodiversitylibrary.org/permissions

This document was created from content at the Biodiversity Heritage Library, the world's largest open access digital library for biodiversity literature and archives. Visit BHL at https://www.biodiversitylibrary.org. 